E3S Web of Conferences 1, 34007 (2013)

DOI: $10.1051 / \mathrm{e} 3$ sconf $/ 20130134007$

(C) Owned by the authors, published by EDP Sciences, 2013

\title{
Trace metal incorporation in otoliths of a territorial coral reef fish (Abudefduf saxatilis) as an environmental monitoring tool
}

\author{
A. T. Herrera-Reveles ${ }^{1,2}$, M. Lemus ${ }^{3}$, B. Marín ${ }^{2}$ and J. L. Prin ${ }^{4}$ \\ ${ }^{1}$ Postgrado en Ecología. Instituto de Zoología y Ecología Tropical. Facultad de Ciencias. Universidad Central de Venezuela. \\ Caracas.Venezuela. anate_herrera@yahoo.com \\ ${ }^{2}$ Laboratorio de Zooplancton. Instituto Oceanográfico de Venezuela. Universidad de Oriente. Núcleo Sucre. Cumaná. \\ Venezuela.baumarm@gmail.com \\ ${ }^{3}$ Laboratorio de Ecofisiología y Ecotoxicología. Instituto Oceanográfico de Venezuela. Universidad de Oriente. Núcleo \\ Sucre. Cumaná. Venezuela.mlemus88@gmail.com \\ ${ }^{4}$ Instituto de Investigaciones en Biomedicina y Ciencias aplicadas. Universidad de Oriente. Núcleo Sucre. Cumaná. \\ Venezuela.joseluis_prin@hotmail.com
}

\begin{abstract}
Trace metal levels in the otolith external layer of newly Abudefduf saxatilis (Pomacentridae) recruits, a common fish of the Caribbean coral reef, were examined as an indicator of recently occupied habitat from the most important coral reefs of the east of Venezuela (Mochima National Park and La Tortuga Island). These otoliths were analyzed trough an Energy-dispersive X-ray spectroscopy (EDS) fixed to scanning electron microscopy (SEM). The five trace metals analyzed $(\mathrm{Cd}, \mathrm{Cu}, \mathrm{Hg}, \mathrm{Pb}$ and $\mathrm{Zn}$ ) were found at external layer of most evaluated otoliths at all localities, in which \%weight of $\mathrm{Pb} / \mathrm{Ca}$ and $\mathrm{Hg} / \mathrm{Ca}$ showed the highest values. These results show the bioavailability of evaluated metals at Mochima National Park and La Tortuga Island, and their significant spatial variations on otoliths make evidence of different concentration of $\mathrm{Cd}, \mathrm{Hg}$ and $\mathrm{Pb}$ in water and/or sediments of these locations.
\end{abstract}

Key Words: Otolith, heavy metals, SEM-EDS, coral reef fish.

\section{Introduction}

Otoliths are calcified tissues located in the inner ear of teleost fish, consisting of alternating layers of aragonite and protein deposited continuously through the lifetime of the fish (Degens et al., 1969). These calcified tissues, may offer a permanent record of metal exposure and reflect a trace metal history of the water environment inhabited by the fish due the potential inclusion of trace metals through substitution for $\mathrm{Ca}$ in the aragonite crystalline matrix or through co-precipitation of another carbonate (Campana, 1999). The fact that the otolith is acellular and metabolically inert means that any elements or compounds accreted onto its growing surface are permanently retained, whereas the continued growth of the otolith from before the time of hatch to the time of death implies that the entire lifetime of the fish has been recorded (Campana and Neilson, 1985, Mugiya et al., 1991).

Numerous studies have used otolith microchemistry for stock discrimination, migratory studies, and connectivity (see Thorrold and Swearer, 2009), but only a few studies have investigated the ability of otoliths to record exposure to pollution, either directly in terms of potentially toxic elements (Geffen et al., 1998, Milton et al. 2000, Ranaldi and Gagnon 2009), or indirectly as proxies for exposure along a pollution gradient (Hanson and Zdanowicz, 1999, Ranaldi and Gagnon 2008a).

The aim of this study was to quantify the concentrations of $\mathrm{Cd}, \mathrm{Cu}, \mathrm{Hg}, \mathrm{Pb}$ and $\mathrm{Zn}$ in otoliths of a territorial coral reef fish (Abudefduf saxatilis) at the most important coral reefs environments of the east of Venezuela (Mochima National Park and La Tortuga Island), as the first 
contribution of this kind of study in Venezuelan marine environments.

\section{Materials and Methods}

Abudefduf saxatilis was selected as the study species because it is a common territorial fish on coral reefs. Newly recruits of $A$. saxatilis were collected at seven localities from the most important coral reefs of the east of Venezuela. Of these, three localities were in Mochima National Park (M1, M4 and M6) and four in La Tortuga Island (T1, T2, T4 and T6). These locations are influenced by upwelling waters. Their water and sediments chemistry could be different due to distance to coast and urbanized populations and by then these chemical differences would be reflected in biogenic carbonates, including fish otoliths.

Examined specimens were obtained since 20 September to 20 October 2010. All individuals were frozen immediately after capture. Sagittal otoliths were extracted using plastic tweezers to minimize contamination and were stored dry in plastic vials.

Each otolith were rinsed using ultrapure water (N-pure, resistivity $18 \mathrm{M} \Omega . \mathrm{cm}$ ), soaked in $15 \%$ semiconductor-grade $\mathrm{H}_{2} \mathrm{O}_{2}$, buffered with $0.05 \mathrm{~N}$ supra-pure $\mathrm{NaOH}$, in acidleached trays for 1 hour, and soaked and rinsed and additional five times with $\mathrm{N}$-pure. Otoliths were dried in air and they were placed on carbon conductive tape above aluminum specimen mounts for scanning electronic microscope. The samples were covered with a chrome coating to create a conduct charge surface using a vacuum evaporator HUS-5GB (Hitachi) for 30 minutes. Ca, Cd, $\mathrm{Cu}, \mathrm{Hg}, \mathrm{Pb}$ and $\mathrm{Zn}$ were measured on the external layer of each otolith by an Energy-dispersive X-ray spectroscopy (EDS) Thermo Noran System Seven with $\mathrm{Si}(\mathrm{Li})$ detector, fixed to scanning electron microscopy (SEM) Hitachi S$800 \mathrm{FE}$. There was used an accelerating voltage of $25 \mathrm{kV}$ during 120 seconds, at several sections of the otolith surface. The elemental quantitative analysis used an automatic background subtraction and a ZAF correction matrix was used to calculate the elemental composition in weight percent. Elemental data were expressed as ratios to $\mathrm{Ca}$ as the elements analyzed are likely substituting for $\mathrm{Ca}$ in the aragonite matrix. The mean and standard deviation is presented by each element at each locality. Prior to analysis, data were checked for homogeneity of variances and normal data distribution. Afterwards, separate ANOVA for each metal were used with locality as the categorical factor. These tests were followed by post hoc Tukey honest significant test. Statistical analyses were performed using SPSS 16.0 statistical package.

\section{Results and Discussion}

The five trace metals analyzed were found at external layer of most otoliths evaluated at all localities, where
$\mathrm{Pb} / \mathrm{Ca}$ and $\mathrm{Hg} / \mathrm{Ca}$ showed the highest values (Table 1). Variations at locations were detected for metal ratios analyzed (Fig. 1).

Differences in $\mathrm{Hg} / \mathrm{Ca}$ between localities were founded (ANOVA; $\mathrm{F}=7.534 ; \mathrm{p}=0.0001$ ); nevertheless these differences are between localities of Mochima National Park (Tukey's post hoc test; $\mathrm{p}<0.03$ ) while the values of this element were similar at La Tortuga Island locations. $\mathrm{Pb} / \mathrm{Ca}$ values are similar at all locations, except T6, which presents the lowest values at La Tortuga Island (ANOVA; $\mathrm{F}=4.890 ; \mathrm{p}=0.0004 ;$ Tukey's post hoc test, $\mathrm{p}=0.02)$. $\mathrm{Cd} / \mathrm{Ca}$ shows differences between localities (ANOVA; $\mathrm{F}=$ 21.189; $\mathrm{p}=0.0001)$, where M4, T1, T2 and T4 have the highest values (Tukey's post hoc test, $\mathrm{p}=0.03)$.

Table 1. Order of \%weight of metal measured relative to $\mathrm{Ca}$ at evaluated different localities

\begin{tabular}{|c|c|}
\hline Localities & $\begin{array}{c}\text { \% weight of metal measured relative to } \\
\mathrm{Ca}\end{array}$ \\
\hline $\mathrm{M} 1$ & $\mathrm{~Pb}>\mathrm{Hg}>\mathrm{Cu}>\mathrm{Zn}>\mathrm{Cd}$ \\
\hline $\mathrm{M} 4$ & $\mathrm{Hg}>\mathrm{Cu}>\mathrm{Pb}>\mathrm{Cd}>\mathrm{Zn}$ \\
\hline $\mathrm{M} 6$ & $\mathrm{~Pb}>\mathrm{Hg}>\mathrm{Zn}>\mathrm{Cu}>\mathrm{Cd}$ \\
\hline $\mathrm{T} 1$ & $\mathrm{Hg}>\mathrm{Pb}>\mathrm{Zn}>\mathrm{Cd}>\mathrm{Cu}$ \\
\hline $\mathrm{T} 2$ & $\mathrm{~Pb}>\mathrm{Hg}>\mathrm{Cd}>\mathrm{Cu}>\mathrm{Zn}$ \\
\hline $\mathrm{T} 4$ & $\mathrm{Hg}>\mathrm{Pb}>\mathrm{Zn}>\mathrm{Cu}>\mathrm{Cd}$ \\
\hline $\mathrm{T} 6$ & \\
\hline
\end{tabular}

Fish have numerous mechanisms for dealing with toxic metals in the environment as $\mathrm{Cd}, \mathrm{Cu}$ and $\mathrm{Hg}$. Some elements may be metabolized, some sequestered so that they become biologically inactive, and others detoxified by conversion into other phases which are then excreted (Xu and Wang, 2002, Wang and Wong, 2003). Mercury belongs to the group of elements that induces metallothionien production, which detoxifies the metal (Pulsford et al., 1992). On this way, some studies have revealed that high and prolonged exposure can overwhelm the defense mechanisms, and excretion may not keep pace with accumulation (Wang and Wong, 2003); thus mercury remained available for incorporation in the otolith, and its incorporation would reflect both concentration and exposure level, like other authors have reported (Geffen et al., 1998). At the same time, some studies found that the $\mathrm{Pb}$ and $\mathrm{Cd}$ otoliths content, are more likely related to the fish environment than to physiological processes, and their concentrations are associated with anthropogenic sources and is not correlated with $\mathrm{pH}$, salinity or other environmental factors (Köck et al., 1996; Ranaldi and Gagnon, 2008a).

$\mathrm{Pb}$ sources at study localities may include $\mathrm{Pb}$-oxides from combusted fuel of different marine ships, like in other coastal zones of Venezuela (Salazar-Lugo, 2009). In 

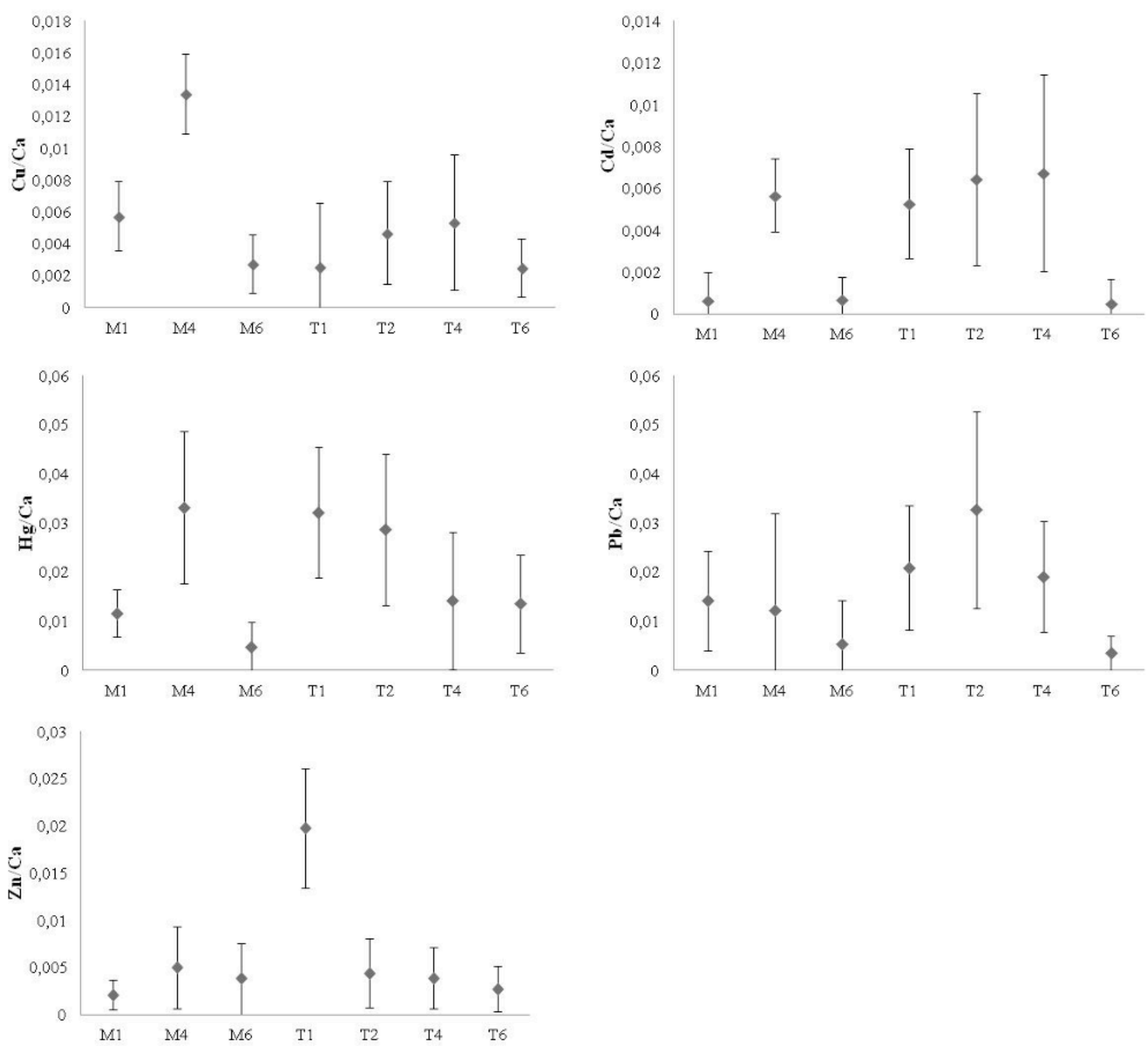

Fig. 1. \% Weight of metal measured relative to $\mathrm{Ca}$ (mean \pm standard deviation) at localities evaluated.

relation to $\mathrm{Cd}$ and $\mathrm{Hg}$ sources, could come from Orinoco river discharge, which has high levels of these metals (Laya, 1992), and they are being transported along the east coast of Venezuela by the prevailing marine currents in the area (Rojas et al., 2002). Furthermore, these are metals which have biogeochemical behavior similar the ones of nutrients; consequently, upwelling waters may be enriched with some metals, constituting the main source of $\mathrm{Hg}$ and Cd to the coastal areas (Cossa et al., 2004, Valdés et al., 2006).

On the other hand, laboratory experiments and field evidences have demonstrated that accumulate $\mathrm{Zn}$ and $\mathrm{Cu}$ in otoliths is predominantly via dietary exposure rather than through waterborne exposure (Campana 1999, Milton et al., 2000, Ranaldi and Gagnon, 2008b). For this reason, the highest measured otolith $\mathrm{Cu} / \mathrm{Ca}$ at $\mathrm{M} 4$ (ANOVA; $\mathrm{F}=$ 12.472; $p=0.0001 ;$ Tukey's post hoc test, $p=0.0001)$ and $\mathrm{Zn} / \mathrm{Ca}$ at $\mathrm{T} 1$ (ANOVA; $\mathrm{F}=10.502 ; \mathrm{p}=0.0001$; Tukey's post hoc test, $\mathrm{p}=0.0001)$, may be indicative of the dietary $\mathrm{Cu}$ and $\mathrm{Zn}$ bioaccumulation in this environment.

\section{Conclusion}

The presence of $\mathrm{Cd}, \mathrm{Cu}, \mathrm{Hg}, \mathrm{Pb}$ and $\mathrm{Zn}$ on the external layers of $A$. saxatilis otoliths shows the bioavailability of these metals at Mochima National Park and La Tortuga Island, where $\mathrm{Pb}$ and $\mathrm{Hg}$ have the highest concentrations. Spatial variations make evidence of different concentration of $\mathrm{Cd}, \mathrm{Hg}$ and $\mathrm{Pb}$ in the water and/or sediments of these locations, whilst spatial differences of $\mathrm{Cu}$ and $\mathrm{Zn}$ may be 
indicative of the dietary bioaccumulations in some localities.

\section{References}

Campana S, Neilson J. Microstructure of fish otoliths. Can. J. Fish Aquat. Sci. 1985; 42:1014-1032.

Campana SE. Chemistry and composition of fish otoliths: pathways, mechanisms and applications. Mar. Ecol. Prog. Ser. 1999; 188, 263-297.

Cossa D, MH Cotte-Krief, RP Masin, J BretaudeauSanjuan. Total mercury in the water column near the shelf edge of the European continental margin. Mar. Chem; 2004. 90: 21-29.

Degens E, W Deuser, R Haedrich. Molecular structure and composition of fish otoliths. Mar. Biol. 1969; 2:105113.

Geffen A, N Pearsen, W Perkins. Metal concentrations in fish otoliths in relation to body composition after laboratory exposure to mercury and lead. Mar. Ecol. Prog. Ser. 1998; 235-245.

Hanson P, V Zdanowicz. Elemental composition of otoliths from Atlantic croaker along an estuarine pollution gradient. J Fish Biol. 1999; 54: 656-668.

Köck G, Noggler M, R Hofer. Pb in otoliths and opercula of arctic char (Salvelinus alpines) from oligotrophic lakes. Water Res. 1996; 30: 1919-1923.

Laya W. Determinación de contenido mercurial en tejidos de peces, sedimentos y agua del bajo Caroní y zona de confluencia con el río Orinoco, estado Bolívar, Venezuela. 1992. B.Sc. dissertation, Universidad de Oriente, Venezuela, $42 \mathrm{pp}$.

Milton DA, C Tenakanai, SR Chenery. Can the movements of barramundi in the Fly River region, Papua New Guinea be traced in their otoliths? Estuar. Coast. Shelf. S. 2000. 50, 855-868.

Mugiya Y, T Hakomori, K Hatsutori. Trace metal incorporation into otolith and scales in the goldfish Carassius auratus. Comp. Biochem. Physiol. Part C. 1991; 99:327-331.

Pulsford AL, KP Ryan, JA Nott. Metals and melanomacrophages in flounder, Platichthys flesus, spleen and kidney. J Mar Biol Assoc UK. 1992; 72: 483-498.
Ranaldi, M, M Gagnon. Trace metal incorporation in otoliths of black bream (Acanthopagrus butcheri Munro), an indicator of exposure to metal contamination. Water Air Soil Poll. 2008a; 194: 3143.

Ranaldi, M, M Gagnon. Zinc incorporation in the otoliths of juvenile pink snapper (Pagrus auratus Foster): the influence of dietary versus waterbone sources. J. Exp. Mar. Biol. Ecol. 2008b; 360: 56-62.

Ranaldi M, M Gagnon. Accumulation of cadmiu, in the otoliths and tissues of juvenile pink snapper (Pagrus auratus Forster) following dietary and waterbone exposuere. Comp Biochem Physiol. C. 2009; 150: 421-427.

Rojas de AL, I Chang, J Agard, I Bekele, R Hubbard. Heavy metal in green mussel (Perna viridis) and oyster (Crassostrea sp.) from Trinidad and Venezuela. Arch. Environ. Contam. Toxicol. 2002; 42: 410-415.

Salazar-Lugo, R. Estado de conocimiento de las concentraciones de cadmio, mercurio y plomo en organismos acuáticos de Venezuela .REDVET. 2009; 10:1 - 15. (Visited 1 May 2011: http://www.veterinaria.org/revistas/redvet/n111109/11 0909.pdf).

Thorrold, S., S. Swearer. Otolith chemistry. In: Green BS, B Mapstone, G Carlos, G Begg. Tropical Fish Otoliths: Information for Assessment, Management and Ecology. 2009. Reviews: Methods and Technologies in Fish Biology and Fisheries 11, Springer, Dordrecht. 313 pp.

Valdés J, DRomán, P Dávila, L Ortlieb, M Guíñez M. Variabilidad estacional de cadmio en un sistema de surgencia costera del norte de Chile (Bahía Mejillones del Sur, 23 S). Rev. Chil. Hist. Nat. 2006; 79: 517535.

$\mathrm{Xu}$ Y, WX Wang. Exposure and potential food chain transfer factors of $\mathrm{Cd}$, Se and $\mathrm{Zn}$ in marine fish Lutjanus argentimaculatus. Mar. Ecol. Prog. Ser. 2002; 238: 173-186.

Wang WX, R Wong. Bioaccumulation kinetics and exposure pathways of inorganic mercury and methylmercury in a marine fish, the sweetlips Plectorhinchus gobbosus. Mar. Ecol. Prog. Ser 2003; 261: 257-268. 